Nota

\title{
STRUCTURAL QUALITY OF A NO-TILLAGE RED LATOSOL 50 MONTHS AFTER GYPSUM APLICATION(1)
}

\author{
Marcelo Marques Lopes Müller ${ }^{(2)}$, Cassio Antônio Tormena ${ }^{(3)}$, Aline \\ Marques Genú( ${ }^{(2)}$, Luiz Fernando Machado Kramer ${ }^{(4)}$, Leandro \\ Michalovicz $^{(4)}$ \& Eduardo Fávero Caires ${ }^{(5)}$
}

\begin{abstract}
SUMMARY
Gypsum application may enhance the soil quality for plants in terms of soil chemical and physical properties. The objective of this study was to evaluate the effects of gypsum application on the structural quality of a no-tillage Red Latosol. The experiment was initiated in September 2005 in Guarapuava-PR, with gypsum applications of $0 ; 4 ; 8$; and $12 \mathrm{Mg} \mathrm{ha}^{-1}$ on the soil surface. In November 2009 , two soil blocks were sampled from the 0-0.3 m layer for visual evaluation of the soil structure quality (Sq) and to determine the aggregate-tensile strength (ATS). Soil penetration resistance $(\mathrm{PR})$ and gravimetric moisture $(\mathrm{H} \%)$ of the 0-0.300 m layer were evaluated, and soil cores were collected (layers 0.000-0.075 and $0.075-0.150 \mathrm{~m}$ ), to determine soil bulk density (BD), total soil porosity (TP), microporosity (Mi), and macroporosity (Ma). Data were subjected to analysis of regression at $5 \%$. No significant effects of gypsum application on ATS and $\mathrm{H} \%$ of aggregates were observed, but for Sq, a quadratic effect $(0.000-0.075 \mathrm{~m})$ and linear increase $(0.075-0.150$ and $0.150-0.300 \mathrm{~m})$ were stated, indicating soil quality decrease, although Sq remained mostly below 3.0, with good to intermediate soil quality. Soil PR increased with gypsum, but also remained below critical levels. No effect was observed for soil $\mathrm{H} \%$ at the moment of PR determination on the field. The gypsum applications decreased $\mathrm{BD}$ in the $0.075-0.150 \mathrm{~m}$ layer, and increased PT and Ma, while in $0.000-0.075 \mathrm{~m}$ some Ma was converted to Mi,
\end{abstract}

\footnotetext{
(1) Presented on the XVIII Reunião Brasileira de Manejo e Conservação do Solo e da Água, Teresina (PI), 8-13/08/2010. Received for publication in March 3, 2011 and approved in April 11, 2012.

(2) Full Professor, Dept. Agronomy, South-Central State University (UNICENTRO), 85040-080, Guarapuava (PR), Brazil. E-mail: mmuller@unicentro.br

(3) Full Professor, Department of Agronomy, Maringá State University, 87020-900, Maringá (PR), Brazil. E-mail: catormena@uem.br

(4) Master student, Postgraduation in Agronomy, UNICENTRO, 85040-080, Guarapuava (PR), Brazil. E-mails: luizfernandokramer@ gmail.com; leandroguarapuava@hotamil.com

(5) Full Professor, Dep. Soil Science and Agricultural Engineer, Ponta Grossa State University, 87020-900, Ponta Grossa (PR), Brazil. E-mail: efcaires@uepg.br
} 
without affecting PT and BD. These last results indicate a gain in soil structural quality by gypsum applications, but the higher scores of soil structure and values of soil penetration resistance, though still below thresholds, should be monitored to prevent limitations to soil use in the future.

Index terms: phosphogypsum, soil physics, visual score, aggregation forces.

\title{
RESUMO: QUALIDADE ESTRUTURAL DE UM LATOSSOLO VERMELHO SOB PLANTIO DIRETO 50 MESES APÓS A APLICAÇÃO DE GESSO
}

\begin{abstract}
A aplicação de gesso pode melhorar a qualidade do solo para as plantas, considerando atributos químicos e físicos do solo. O objetivo deste estudo foi avaliar os efeitos de doses de gesso aplicadas em um Latossolo Vermelho sob plantio direto em sua qualidade estrutural. $O$ experimento iniciou-se em setembro de $2005 \mathrm{em}$ Guarapuava-PR, com a aplicação das doses de gesso na superfície do solo: 0, 4, 8 e $12 \mathrm{Mg} \mathrm{ha}^{-1}$. Dois monólitos de solo foram coletados em novembro de 2009 na profundidade de 0,0-0,300 m, para avaliação visual da qualidade estrutural do solo (Sq) e para obter agregados a fim de determinar sua resistência tênsil (ATS). A resistência do solo à penetração (RP) e a umidade gravimétrica (H\%) do solo foram avaliadas na profundidade de 0,000-0,300 $\mathrm{m}$, e amostras indeformadas foram coletadas nas profundidades de 0,000-0,075 e 0,075-0,150 m para determinar a densidade solo (Ds), porosidade total (PT), microporosidade (Mi) e macroporosidade (Ma). Os dados foram submetidos à análise de regressão a 5\%. Não houve efeito significativo da aplicação de gesso sobre ATS e U\% dos agregados, mas houve efeito quadrático (0,000-0,075 m) $e$ aumento linear (0,075-0,150 e 0,150-0,300 m) de $S q$, o que representaria diminuição da qualidade estrutural do solo; contudo, os valores de Sq permaneceram majoritariamente abaixo de 3,0, qualidade entre boa e intermediária. A RP também aumentou com o uso do gesso, porém, novamente, os valores mantiveram-se abaixo de níveis críticos (2-3 MPa). $N a \tilde{o}$ houve efeito sobre a $U \%$ do solo no momento da determinação da RP no campo. Com o gesso, a Ds diminuiu na camada de 0,075-0,150 m, concomitantemente com o aumento de PT e Ma, enquanto na camada de 0,000-0,075 m parte da Ma foi convertida em Mi, sem alterar PT e Ds. Esses últimos resultados representam ganho na qualidade estrutural do solo em função da aplicação do gesso, mas os aumentos de escore da estrutura do solo e de resistência à penetração, mesmo permanecendo abaixo dos limites críticos, precisam ser monitorados a fim de garantir que não representarão limitações ao uso do solo no futuro.
\end{abstract}

Termos de indexação: fosfogesso, física do solo, escore visual, forças de agregação.

\section{INTRODUCTION}

More than $60 \%$ of the cropland of Brazil is managed in no-tillage (NT) systems (Mello \& Raij, 2006), $70 \%$ continuous-time (Derpsch \& Friedrich, 2009). Many areas have reached 20 years of NT, with appropriate yields after long periods without liming (Anghinoni \& Salet, 2000). This does not mean that lime is now less relevant, but prolonged effects of long-term (seven years or more) NT begin to show (Kaminski et al., 2005), while liming makes less difference in yield responses, indicating other factors as more limiting.
The effect of lime is restricted to the application site (Caires et al., 2004) and since only a minority of NT farmers in Brazil incorporate it into the soil, the values of $\mathrm{pH}$, aluminum (Al), calcium (Ca), and magnesium $(\mathrm{Mg})$ are little altered in the soil subsurface (Ernani et al., 2001), raising concern about shallow rooting and crop susceptibility to drought. Besides, surface-near soil compaction in NT is a fact (Tormena et al., 1998), with negative effects on crop growth by reducing water and nutrient availability (Giarola et al., 2009a), supporting the fact that, in chemically fertile NT areas, crop yield variability may be better explained 
by soil physical indicators such as infiltration (Santi, 2007). Management zone studies for precision agriculture in NT showed that in drier years, zones are more precisely defined when the levels of soil organic matter (SOM), compaction and water storage are taken into consideration (Santos et al., 2004).

As most crop roots are close to the surface, i.e., $70-80 \%$ of the soybean root mass in the $0.00-0.15 \mathrm{~m}$ layer (Gregory, 1992), the very thin soil layers with chemically adequate conditions for rooting along with compaction problems are probably the cause for important yield decreases under NT in drier years. This is particularly true in view of the recent repetitions of La Niña, as once again in the 2010-2011 season, causing a great water deficit in southern Brazil (CPTEC-INPE, 2010). Berlato et al. (2005) stated that climatic instability strongly influences the temporal yield variability in Rio Grande do Sul, where NT is widely used.

This scenario has led to a new interest in gypsum. Aside from improving the soil physical properties in some cases, it is also a soluble source of calcium (Ca) and sulfur (S) for plant nutrition (Shainberg et al., 1989) and complements lime in acidic soils, to control $\mathrm{Al}$ toxicity and increase $\mathrm{Ca}$ levels in the subsurface (Ernani, 1986; Ernani et al., 1993), improving conditions for deeper rooting. Caires et al. (2001) found better root distribution of barley in deeper soil layers with gypsum applied to the soil surface in NT, especially when combined with surface liming, improving the nutrient uptake in years of water stress.

Gypsum is widely applied to poorly structured sodic/clayey soils with infiltration and runoff problems (Lebron et al., 2002; Norton \& Donstova, 1998). In sodium-affected soils, it improves the soil structure (Malik et al., 1991) by increasing flocculation, aggregate stability (AS) and water infiltration, although the effects on physical properties of non-sodic soils are not well studied (Tirado-Corbala, 2009). Thomas et al. (1995) observed a $15 \%$ increase in wheat and sorghum grain yield after gypsum application to a red-brown soil, which was explained by a higher soil-water storage.

Muneer \& Oades (1989) recorded increased AS after gypsum application. Agassi et al. (1982) reported that runoff was reduced by $43 \%$ with $5 \mathrm{Mg} \mathrm{ha}^{-1}$ of gypsum and was more beneficial when spread over the soil surface than when incorporated. Mohandas et al. (1983) stated that gypsum improved the structure of fine-textured soil, increasing water infiltration and the root penetration capacity. After up to 12 years of gypsum application to NT soils in Ohio, Tirado-Corbala (2010) observed higher bulk density in the surface than in the deeper soil layers, larger water stable aggregates (most layers and soils), and higher saturated hydraulic conductivity in gypsum-treated than in control soils. The positive effect of long-term gypsum use on the soil physical properties was explained by the redistribution of $\mathrm{Ca}$ throughout the profile.

Many indicators may be used to evaluate the soil structural quality, although some are still not very common in Brazil. Tensile strength of aggregates (ATS) is a very sensitive indicator of the soil structural condition (Dexter \& Kroesbergen, 1985) and may be influenced by factors such as SOM and cementing agents (Kay \& Dexter, 1992). Studying a Red Latosol under NT, Tormena et al. (2008) found that ATS was not influenced by the organic carbon content of the aggregates, but was very sensitive to evaluate $\mathrm{Sq}$ under different management and crop systems.

Although well-developed for temperate soils, few semiquantitative field measurements have been validated and are used in tropical/subtropical regions. The visual evaluation of the soil structure assigns scores of structural quality to the soil, based on the morphology and resistance of structural units to manual rupture. Giarola et al. (2010) evaluated the method of Ball et al. (2007) in cultivated and noncultivated soils of Paraná and concluded that this method can be applied to Oxisols of the State under NT.

The objective of this paper was to evaluate the effects of gypsum rates applied to the surface on soil structural quality of a no-tillage Red Latosol.

\section{MATERIAL AND METHODS}

Field evaluations were performed in November 2009, on the Fazenda Santa Cruz, 50 months after gypsum application in a long-term experiment in Guarapuava, Paraná, Brazil ( $25^{\circ} 23^{\prime} 02^{\prime}$ S, $51^{\circ} 29^{\prime}$ $15,1043 \mathrm{~m}$ asl) (IBGE, 2009). The climate is $\mathrm{Cfb}$, according to Köppen's classification, with mild summers and cold winters, when frosting occurs (IAPAR, 2000). The soil is a dystrophic heavy clayey Red Latosol (Oxisol) after 19 years of continuoustime NT, and the initial characterization of the soil revealed means of 656,267 and $73 \mathrm{~g} \mathrm{~kg}^{-1}$ of clay, silt and sand, respectively, in the layers between 0.00-0.40 m (adapted from Maschietto, 2009).

A random block design was used, with four replications. Four gypsum rates were applied to the soil surface in September 2005: 0; 4; 8; and $12 \mathrm{Mg} \mathrm{ha}^{-1}$. In November 2009, two soil monoliths of $0.30 \times 0.15 \times 0.10 \mathrm{~m}$ were sampled per plot $(7 \times 7 \mathrm{~m})$ 
in the 0.0-0.3 m layer with a spade: one used for visual evaluation of soil structure (VESS) and the other sieved to obtain 40 aggregates from each. The aggregates were oven-dried $\left(40^{\circ} \mathrm{C}, 24 \mathrm{~h}\right)$, weighed and subjected to an electronic linear actuator to determinate the tensile strength of aggregates (ATS), with a constant velocity of $0.03 \mathrm{~mm} \mathrm{~s}^{-1}$ (Imhoff et al., 2002). Aliquots of each aggregate were collected after ATS test, weighed and dried $\left(105^{\circ} \mathrm{C}\right.$, $48 \mathrm{~h}$ ) to determine gravimetric moisture (H\%). ATS was calculated (Dexter \& Kroesbergen, 1985) as: ATS $=0.576\left(\mathrm{~F} / \mathrm{D}^{2}\right), 0.576$ being the proportionality coefficient, $\mathrm{F}$ the force $(\mathrm{N})$ necessary to break the aggregate, and $\mathrm{D}$ the effective diameter $(\mathrm{m})$ of the aggregate, calculated as: $\mathrm{D}=\mathrm{Dm}(\mathrm{M} / \mathrm{M} 0)^{1 / 3}, \mathrm{M}$ being the mass $(\mathrm{g})$ of the individual aggregate, M0 the average aggregate mass $(\mathrm{g})$ on each treatment, and Dm the average $(\mathrm{mm})$ aggregate diameter, which is the mean between apertures of the sieves used on the laboratory $[(12.5+19.0) / 2=15.75 \mathrm{~mm}]$.

Monoliths used for VESS were studied by shape, size and resistance to manual rupture using a reference guide with photos and definitions, to help define one of the 1 to 5 structural quality scores (Sq) defined (Ball et al., 2007; Giarola et al., 2010). As soil layers with varying thickness received different Sq values, data were treated as weighted mean for $0.000-0.075,0.075-0.150$ and $0.150-0.300$ layers, in a manner similar to that demonstrated by Giarola et al. (2009b).

Soil penetration resistance (PR) was evaluated on the field with a Falker ${ }^{\circledR}$ penetrometer, each $0.01 \mathrm{~m}$ until $0.30 \mathrm{~m}$ depth at three points per plot (subsample), according to Tormena \& Roloff (1996). On every evaluation point, soil samples were collected with an auger each $0.10 \mathrm{~m}$ until $0.30 \mathrm{~m}$ depth, for gravimetric moisture $(\mathrm{H} \%)$ determination (Embrapa, 1979). Data of PR and H \% were also treated as weighted mean for the same soil layers used for Sq.

Soil core samples were collected from the 0.000-0.075 and 0.075-0.150 m layers, with steel cylinders $\left(0.0001 \mathrm{~m}^{3}\right)$, using an electric drilling device. Microporosity (Mi) was determined by the volumetric water content at $-0.006 \mathrm{MPa}$ using a tension table, and macroporosity (Ma) was obtained by the difference between total soil porosity (TP) and Mi, while TP was obtained from the relationship between soil bulk density and particle density [TP $=1-(\mathrm{BD} / \mathrm{PD})]$. Bulk density $(\mathrm{BD})$ was calculated using the soil dry mass $\left(105-110^{\circ} \mathrm{C}, 48 \mathrm{~h}\right)$ and sample (core) volume. Soil particle density (PD) was determined using the flask method (ethyl alcohol), with aliquots of soil samples after the tension table procedure. The complete protocol of the methodologies for these measurements were described by Blake \& Hartge (1986), Danielson \&
Sutherland (1986) and Embrapa (1979).

Data were subjected to analysis of regression at $5 \%$, and regression models were chosen based on the higher significance level by analysis of variance (ANOVA) of the regression analysis.

\section{RESULTS AND DISCUSSION}

Gypsum rates had no significant effect on the $\mathrm{H} \%$ and ATS of the aggregates (Figure 1), which had an experimental mean of $75.40 \mathrm{KPa}$ and coefficient of variation (CV) of $19.68 \%$, considered medium (Gomes, 1985). Studying a Red Latosol under NT at Paraná, Tormena et al. (2008) found ATS between 83.20-97.20 KPa and recorded significant treatment effects even with higher CV (44.21-56.02 \%). This different trend may be related to the fact that the authors worked with other crop rotations and mechanical treatments, with a consequently more intense impact on soil physics than the indirect physicochemical effects in this study. The lower ATS observed here, on the other hand, may be due to the $\mathrm{H} \%$ of the aggregates, $6.18 \%$ (experimental mean) compared to $2.50-2.90 \%$ in the above study, once aggregates with higher $\mathrm{H} \%$ may suffer plastic deformation before tensile breakage (Dexter \& Watts, 2000).

Another possible reason for no significant treatment effect on ATS would be the fact that the aggregates came from a whole soil core of 0.00$0.30 \mathrm{~m}$, as in previous studies (Imhoff et al., 2002; Tormena et al., 2008). The separation of aggregates by natural morphological layers, as identified

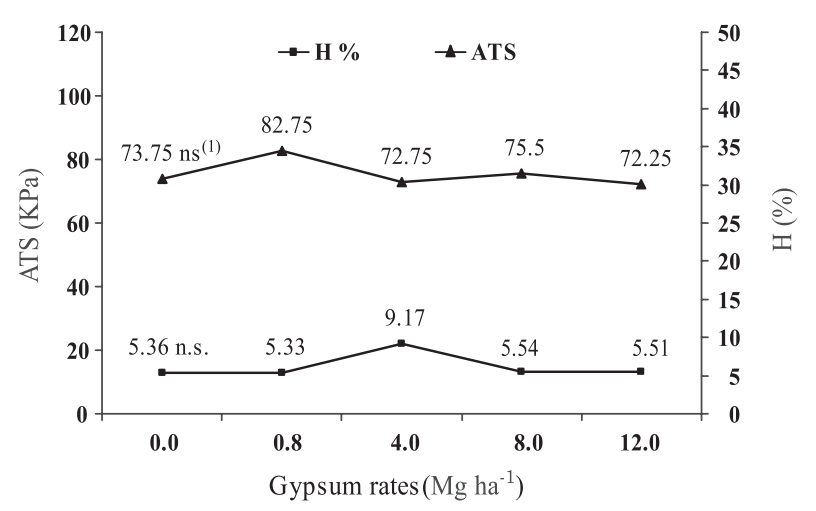

Figure 1. Aggregate tensile strength (ATS) and gravimetric moisture (U) found in the layer 0.00-0.30 $\mathrm{m}$ of a no-tillage Red Latosol, 50 months after gypsum applications on the soil surface (Guarapuava, 2009). (1)ns: nonsignificant by the ANOVA of the regression analysis. 
by VESS (Giarola et al., 2009b) or at arbitrary depths, prior to the ATS test, could have produced better differentiation of treatments, and should be considered in future studies.

Different morphological features of the soil monoliths were observed and there was a response in Sq to the treatments (Table 1). Gypsum rates produced quadratic effects on $\mathrm{Sq}$ in the 0.000 $0.075 \mathrm{~m}$ layer, while in the $0.075-0.150$ and 0.150 $0.300 \mathrm{~m}$ layers, Sq responded with a linear increase to gypsum. Quadratic effects on the top layer and linear effects in the subsurface could mean that gypsum had more intense effects on aggregation forces in the surface layer, with greater increase in aggregate size (macroaggregates).

According to Ball et al. (2007) and Giarola et al. (2010), the increase of Sq would mean decreased soil structural quality, identified by larger size aggregates, more difficult to break, less porous, where roots are concentrated around aggregates and in cracks (Giarola et al., 2010). In this study, the main morphological characteristic responsible for Sq assessment was aggregate size, increasing with increasing gypsum rates. However, since no rooting decrease, for example, was noted, it would be a speculation to conclude that gypsum applications cause a decrease in the soil structural quality, only based on the Sq increase in this case.

Moreover, Ball et al. (2007) defined Sq scores between 1.0-2.0 as good structural quality, between 2.0-3.0 as intermediate and between $3.0-5.0$ as degraded. The observation that most Sq values were between $1.0-2.0$ in the $0.000-0.075 \mathrm{~m}$ layer and between $2.0-3.0$ in the $0.075-0.150$ and $0.150-$ $0.300 \mathrm{~m}$ layers, means that soil structure was from good to intermediate, even at the gypsum rate of $12 \mathrm{Mg} \mathrm{ha}{ }^{-1}$. Systems with Sq scores between 1 and 3 are considered to be in acceptable soil physical conditions (Ball et al., 2007).

The observed Sq score increase with gypsum could in fact indicate positive effects on the soil aggregation forces, in agreement with findings of Rosa Junior et al. $(1994,2006)$ that gypsum can act as structure conditioner, favoring soil aggregation. According to Brady \& Weil (2008), gypsum has been found to be effective in improving the physical condition of many soils, from highly weathered acid soils to some low-salinity, high-sodium soils of semiarid regions, providing enough electrolytes to promote flocculation and inhibit aggregate dispersion.

Maschietto (2009), who initially set up this experiment for soil fertility studies, observed that the top soil layer was the one with greatest

Table 1. Soil structural quality (Sq) scores, penetration resistance (PR) and gravimetric moisture in different layers of a Red Latosol under no-tillage, 50 months after application of gypsum rates to the soil surface (Guarapuava, 2009)

\begin{tabular}{|c|c|c|c|c|}
\hline Layer & Gypsum & $\mathrm{Sq}$ & PR & $\mathbf{H}$ \\
\hline $\mathrm{m}$ & $\mathrm{Mg} \mathrm{ha}^{-1}$ & - & $\mathrm{MPa}$ & $\%$ \\
\hline $0.000-0.075$ & $\begin{array}{c}0.0 \\
0.8 \\
4.0 \\
8.0 \\
12.0 \\
\text { Effect } \\
\mathrm{R}^{2} \\
\mathrm{CV}(\%)\end{array}$ & $\begin{array}{l}1.37 \\
1.25 \\
1.80 \\
2.13 \\
1.55 \\
\mathrm{Q}^{* *(1)} \\
0.83 \\
19.51\end{array}$ & $\begin{array}{c}0.37 \\
0.28 \\
0.39 \\
0.49 \\
0.42 \\
\text { n.s. } \\
- \\
32.39\end{array}$ & $\begin{array}{c}41.75 \\
44.50 \\
42.50 \\
42.00 \\
43.00 \\
\text { n.s. } \\
- \\
2.43\end{array}$ \\
\hline $0.075-0.150$ & $\begin{array}{c}0.0 \\
0.8 \\
4.0 \\
8.0 \\
12.0 \\
\text { Effect } \\
\mathrm{R}^{2} \\
\mathrm{CV}(\%)\end{array}$ & $\begin{array}{c}1.97 \\
2.18 \\
2.60 \\
2.98 \\
2.97 \\
\mathrm{~L}^{* *} \\
0.87 \\
15.49\end{array}$ & $\begin{array}{c}1.01 \\
1.02 \\
1.33 \\
1.24 \\
1.27 \\
\mathrm{~L}^{* *} \\
0.54 \\
11.82\end{array}$ & $\begin{array}{c}42.00 \\
43.00 \\
41.50 \\
42.00 \\
42.50 \\
\text { n.s. } \\
- \\
1.90\end{array}$ \\
\hline $0.150-0.300$ & $\begin{array}{c}0.0 \\
0.8 \\
4.0 \\
8.0 \\
12.0 \\
\text { Effect } \\
\mathrm{R}^{2} \\
\mathrm{CV}(\%)\end{array}$ & $\begin{array}{c}2.34 \\
2.37 \\
3.15 \\
2.87 \\
2.93 \\
\mathrm{~L}^{*} \\
0.55 \\
10.80\end{array}$ & $\begin{array}{c}1.39 \\
1.47 \\
1.74 \\
1.60 \\
1.67 \\
\mathrm{~L}^{*} \\
0.45 \\
8.27\end{array}$ & $\begin{array}{c}44.00 \\
43.75 \\
42.50 \\
43.75 \\
43.00 \\
\text { n.s. } \\
- \\
2.29\end{array}$ \\
\hline
\end{tabular}

\footnotetext{
${ }^{(1)} \mathrm{ns},{ }^{*}$ and ${ }^{* *}$ : non-significant, significant at 5 and $1 \%$, respectively, by the ANOVA of the regression analysis; Q: quadratic, L: linear.
} 
$\mathrm{Ca}$ increase and $\mathrm{Mg}$ decrease, and $\mathrm{Ca}$ is accepted to be a critical element for SOM and aggregate stabilization, in view of its role in the formation of clay-polyvalent cation-organic matter complexes, as Six et al. (2004) demonstrated in their review on this issue.

Soil PR was not affected by gypsum in the top layer, but was linearly increased by gypsum rates in the $0.075-0.150$ and $0.150-0.300$ m layers (Table 1 ). As discussed above, aggregation forces enhanced by $\mathrm{Ca}$ increase due to gypsum application may have resulted in larger aggregates, indicated by the $\mathrm{Sq}$ score increase with gypsum rates. According to Misra et al. (1986), an increase in aggregate size increases the axial root growth force required for aggregate penetration, so PR measured by the penetrometer would also be increased with gypsum.

Interestingly, that even though gypsum increased PR in subsurface (Table 1), values were mostly low, under $0.49,1.33$ and $1.74 \mathrm{MPa}$ in the $0.000-0.075 \mathrm{~m}$, 0.075-0.150 $\mathrm{m}$ and $0.150-0.300 \mathrm{~m}$, not reaching critical 2.0-3.0 $\mathrm{MPa}$, which may reduce root growth in some species by about $50 \%$, according to Bengough \& Mullins (1990). In addition, PR means were below $2.31-2.78 \mathrm{MPa}$ found in the $0.00-0.15 \mathrm{~m}$ of a Red Latosol by Tormena et al. (2007), which may be due to the higher soil water content, resulting in reduced cohesion of soil particles and reduced PR (Silva et al., 2002). No gypsum effect was observed for $\mathrm{H} \%$ and there was little variation of $\mathrm{H} \%$ among soil depths, with an experimental mean of $42.80 \%$. This ensures that PR effects were not due to $\mathrm{H} \%$ differences.
Soil BD was affected by treatments only in the 0.075-0.150 m, where BD decreased linearly with gypsum rates (Table 2). This may also be related to a larger aggregate size observed in function of gypsum in the same layer $(\mathrm{Sq})$, which may have led to increased porosity between aggregates (macropores). Data from the $0.000-0.150 \mathrm{~m}$ layer (good to intermediate $\mathrm{Sq}$ scores and PR below critical values), BD results also indicated good soil structural condition (Table 1), with average 1.074 and $1.176 \mathrm{Mg} \mathrm{m}^{-3}$ for the layers $0.000-0.075 \mathrm{~m}$ and $0.075-0.150 \mathrm{~m}$, respectively. These values are below the $1.250 \mathrm{Mg} \mathrm{m}^{-3}$ reported by Derpsch et al. (1991) for a Red Latosol under NT, and below 1.300$1.400 \mathrm{Mg} \mathrm{m}^{-3}$ proposed by Reichert et al. (2003) for clay soils, as limits or as critical BD values above which strong mechanical restrictions to root growth set in.

There was a linear increase of PT in function of gypsum rates in the $0.075-0.150 \mathrm{~m}$, in consonance to linear decrease of $\mathrm{BD}$ (Table 2). This result is related to the linear increase of $\mathrm{Ma}$ in function of gypsum rates in this layer, supporting the above arguments of greater aggregate size with gypsum and the resulting increased porosity between larger aggregates. As is known, gypsum is used in poorly structured soils to mitigate runoff by reducing water infiltration problems (Norton \& Donstova, 1998; Lebron et al., 2002). Mohandas et al. (1983) stated that gypsum improved the structure of fine textured soil so that water infiltration was enhanced, and water infiltration into the soil occurs through the macropores (Stone et al., 2002).

Table 2. Soil bulk density (BD), total soil porosity (TP), microporosity (Mi) and macroporosity (Ma) in different layers of a Red Latosol under no-tillage, 50 months after application of gypsum rates on the soil surface (Guarapuava, 2009)

\begin{tabular}{|c|c|c|c|c|c|}
\hline Depth & Gypsum & BD & TP & Mi & Ma \\
\hline $\mathrm{m}$ & $\mathrm{Mg} \mathrm{ha}^{-1}$ & $\mathrm{Mg} \mathrm{m}^{-3}$ & 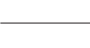 & $\mathrm{m}^{3} \mathrm{~m}^{-3}$ & \\
\hline $0.000-0.075$ & $\begin{array}{c}0.0 \\
0.8 \\
4.0 \\
8.0 \\
12.0 \\
\text { Effect } \\
\mathrm{R}^{2} \\
\mathrm{CV}(\%)\end{array}$ & $\begin{array}{c}1.087 \\
1.065 \\
1.055 \\
1.075 \\
1.087 \\
\text { n.s. }^{1} \\
- \\
6.14\end{array}$ & $\begin{array}{c}0.602 \\
0.610 \\
0.614 \\
0.607 \\
0.604 \\
\text { n.s. } \\
- \\
2.78\end{array}$ & $\begin{array}{c}0.522 \\
0.510 \\
0.537 \\
0.536 \\
0.551 \\
\mathrm{~L}^{* *} \\
0.84 \\
1.77\end{array}$ & $\begin{array}{c}0.072 \\
0.100 \\
0.078 \\
0.070 \\
0.053 \\
L^{*} \\
0.63 \\
15.36\end{array}$ \\
\hline & CV (\%) & 6.14 & 2.78 & 1.77 & 15.36 \\
\hline $0.075-0.150$ & $\begin{array}{c}0.0 \\
0.8 \\
4.0 \\
8.0 \\
12.0 \\
\text { Effect } \\
\mathrm{R}^{2} \\
\mathrm{CV}(\%)\end{array}$ & $\begin{array}{c}1.190 \\
1.210 \\
1.150 \\
1.190 \\
1.142 \\
\mathrm{~L}^{*} \\
0.41 \\
2.28\end{array}$ & $\begin{array}{c}0.589 \\
0.582 \\
0.603 \\
0.589 \\
0.605 \\
L^{*} \\
0.41 \\
1.02\end{array}$ & $\begin{array}{c}0.533 \\
0.523 \\
0.519 \\
0.525 \\
0.519 \\
\text { n.s. } \\
- \\
1.76\end{array}$ & $\begin{array}{c}0.056 \\
0.058 \\
0.084 \\
0.064 \\
0.086 \\
L^{*} \\
0.51 \\
10.86\end{array}$ \\
\hline
\end{tabular}

(1) $\mathrm{ns},{ }^{*}$ and $* *$ : non-significant, significant at 5 and to $1 \%$, respectively, by the ANOVA of the regression analysis; L: linear. 
On the contrary, Ma decreased linearly in function of gypsum in 0.000-0.075 m, which was accompanied by a linear $\mathrm{Mi}$ increase in this layer (Table 2), in other words, part of the macropores were transformed into micropores. These results suggest that gypsum increased soil aggregation, as discussed for $\mathrm{Sq}$ scores, once Mi correspond to intra-aggregate pores (Othmer et al., 1991). Micropores are strongly influenced by aggregation, and little influenced by BD alterations under tractor and equipment traffic (Silva \& Kay, 1997), which was absent as variation source in this experiment.

In this study, the replacement of macropores by micropores was enough to prevent a significant alteration of PT and consequently BD in the 0.000 $0.075 \mathrm{~m}$ layer, although the process of converting $\mathrm{Ma}$ into $\mathrm{Mi}$ is very often associated to $\mathrm{BD}$ and compaction increases (Silva et al., 2006), which is a known surface-near characteristic of NT systems (Stone et al., 2002). Studying gypsum application periods to NT soils of Ohio, Tirado-Corbala (2010) observed higher BD on topsoil and lower on subsoil for gypsum-treated soils compared to controls, concluding that gypsum had a positive effect on soil physical properties due to the redistribution of Ca throughout the profile as previously reported by Maschietto (2009).

A positive effect of gypsum rates on maize nutrition and yield was found, which clearly resulted in soil chemical modifications (Maschietto, 2009). However, our results show that gypsum also affected soil physical properties after 50 months. This should be taken into consideration for a more comprehensive discussion on effects of gypsum on plant nutrition and crop yield over time in NT soils, especially under water stress, as more frequently observed in recent years with La Niña ocurrence, considering that gypsum can improve root distribution in the deeper soil layers, as observed by Caires et al. (2001) with barley.

Additionally, since the micropores retain water available to plants (Brady \& Weil, 2008), the effect of gypsum of increasing $\mathrm{Mi}$ in the top layer, where nutrients are concentrated in NT soils (Cassol et al., 2002), also observed in the experiment (Maschietto, 2009) may have enhanced water/ nutrient availability to crops. As gypsum also increased TP and Ma in the subsurface layer, and $\mathrm{PR}$ was not critical in the 0-0.3 m layer, gypsum may have favored root distribution in the deeper soil layers, resulting in better nutrient absorption and higher maize yield, confirming that surface gypsum applications increase growth and water and nutrient uptake by plants (Carvalho \& Raij, 1997).

\section{CONCLUSIONS}

Fifty months after gypsum application, some macroposity was converted to microporosity in the $0.000-0.075 \mathrm{~m}$ layer, while in the $0.075-0.150 \mathrm{~m}$ layer soil porosity was increased and soil density reduced, representing a structural quality gain of the soil. On the other hand, the soil structure scores and penetration resistance were increased in the 0-0.3 m layer, and even though thresholds were not reached, further studies are necessary to take measures that prevent these features from becoming a problem for soil use in the future.

\section{ACKNOWLEDGEMENTS}

The authors wish to thank the Ph.D. student Susana C. Blum (ESALQ/USP), for allowing us to use her experimental area. To Mr. Renato Cruz, owner of the Fazenda Santa Cruz (Guarapuava-PR), for granting permission to carry out this research on his property.

\section{LITERATURE CITED}

AGASSI, M.; MORIN, J. \& SHAINBERG, I. Laboratory studies of infiltration and runoff control in semi-arid soils in Israel. Geoderma, 28:345-356, 1982.

ANGHINONI, I. \& SALET, R.L. Reaplicação de calcário no sistema plantio direto consolidado. In: KAMINSKI, J. Uso de corretivos da acidez do solo no plantio direto. Pelotas: Núcleo Regional Sul, 2000. p.41-59. (Boletim Técnico, 4)

ANGHINONI, I. \& SALET, R.L. Reaplicação de calcário no sistema plantio direto consolidado. In: BALL, B.C.; BATEY, T. \& MUNKHOL, M.L.J., eds. Field assessment of soil structural quality - a development of the Peerlkamp test. Soil Use Manag., 23:329-337, 2007.

BALL, B.C.; BATEY, T.; MUNKHOLM, L.J. Field assessment of soil structural quality - a development of the Peerlkamp test. Soil Use and Management, v.23, p.329-337, 2007.

BENGOUGH, A.G. \& MULLINS, C.E. Mechanical impedance to root growth: A review of experimental techniques and root growth responses. J. Soil Sci., 41:341-358, 1990.

BERLATO, M.A.; FARENZENA, H. \& FONTANA, D.C. Associação entre El Nino Oscilação Sul e a produtividade do milho no Estado do Rio Grande do Sul. Pesq. Agropec. Bras., 39:423-432, 2005.

BLAKE, G.R. \& HARTGE, K.H. Bulk density. In: KLUTE, A., ed. Methods of soil analysis: Physical and mineralogical methods. Madison, ASA, 1986. p.363-375. 
BRADY, N.C. \& WEIL, R.R. The nature and properties of soils. 14.ed. Upper Saddle River: Pearson Prentice Hall, 2008. 965 p.

CAIRES, E.F.; FELDHAUS, I.C. \& BLUM, J. Crescimento radicular e nutrição da cevada em função da calagem e aplicação de gesso. Bragantia, 60:213-223, 2001.

CAIRES, E.F.; KUSMAN, M.T.; BARTH, G.; GARBUIO, F.J. \& PADILHA, J.M. Alterações químicas do solo e resposta do milho à calagem e aplicação de gesso. R. Bras. Ci. Solo, 28:125-136, 2004.

CARVALHO, M.C.S. \& RAIJ, B. van. Calcium sulphate, phosphogypsum and calcium carbonate in the amelioration of acid subsoils for root growth. Plant Soil, 192:37-48, 1997.

CASSOL, E.A.; LEVIEN, R.; ANGHINONI, I. \& BADELUCCI, M.P. Perdas de nutrientes por erosão em diferentes métodos de melhoramento de pastagem nativa no Rio Grande do Sul. R. Bras. Ci. Solo, 26:705-712, 2002.

CPTEC-INPE. Centro de Previsão do Tempo e Estudos Climáticos - Instituto Nacional de Pesquisas Espaciais. La Niña perde força no Norte do RS. Disponível em: <http:// www7.cptec.inpe.br/noticias/noticia/15613>. Acesso em: 27 dez. 2010.

DANIELSON, R.E. \& SUTHERLAND, P.L. Porosoty. In: KLUTE, A., ed. Methods of soil analysis; Physical and mineralogical methods. Madison, American Society of Agronomy, 1986. p.443-461.

DERPSCH, R. \& FRIEDRICH, T. Development and current status of no-till adoption in the world. In: TRIENNIAL CONFERENCE OF THE INTERNATIONAL SOIL TILLAGE RESEARCH ORGANIZATION, 18., Izmir, 2009. Proceedings... Izmir, Turkey, ISTRO, 2009. CD ROM.

DERPSCH, R.; ROTH, C.H.; SIDIRAS, N. \& KÖPKE, U. Controle da erosão no Paraná, Brasil: Sistemas de cobertura do solo, plantio direto e preparo conservacionista do solo. Londrina, Fundação Instituto Agronômico do Paraná, 1991. 272p.

DEXTER, A.R. \& KROESBERGEN, B. Methodology for determination of tensile strength of soil aggregates. J. Agric. Eng. Res., 31:139-147, 1985.

DEXTER, A.R. \& WATTS, C. Tensile strength and friability. In: SMITH, K. \& MULLINS, C., eds. Soil and environmental analysis: Physical methods. 2.ed. New York, Marcel Dekker, 2000. p.401-430.

EMPRESA BRASILEIRA DE PESQUISA AGROPECUÁRIA - EMBRAPA. Serviço Nacional de Levantamento e Conservação dos Solos. Manual de métodos de análise do solo. Rio de Janeiro, SNLCS, 1979. Não Paginado.

ERNANI, P.R. Alterações em algumas características químicas na camada arável do solo pela aplicação de gesso agrícola sobre a superfície de campos nativos. R. Bras. Ci. Solo, 10:241-245, 1986.

ERNANI, P.R.; CASSOL, P.C.; MORIGUTII, H.; GARCIA, M.M. \& VACARO, M. Aplicação de gesso agrícola e lixiviação de potássio em solos catarinenses. Univers. Desenvolv., 1:7-16, 1993.
ERNANI, P.R.; RIBEIRO, M.S. \& BAYER, C. Modificações químicas em solos ácidos ocasionadas pelo método de aplicação de corretivos da acidez e de gesso agrícola. Sci. Agric., 58:825-831, 2001.

GIAROLA, N.F.B.; BRACHTVOGEL, E.L.; FONTANIVA, S.; PEREIRA, R.A. \& FIOREZE, S.L. Cultivares de soja sob plantio direto em Latossolo Vermelho compactado. Acta Sci. Agron., 31:641-646, 2009a.

GIAROLA, N.F.B.; SILVA, A.P.; TORMENA, C.A.; BALL, B. \& ROSA, J.A. Visual soil structure quality assessment on Oxisols under no-tillage system. Sci. Agric., 67:479-482, 2010.

GIAROLA, N.F.B.; TORMENA, C.A.; SILVA, A.P. \& BALL, B. Método de avaliação visual da qualidade da estrutura aplicado a Latossolo Vermelho Distroférrico sob diferentes sistemas de uso e manejo. Ci. Rural, 39:2531-2534, 2009b.

GOMES, F.P. Curso de estatística experimental. 13.ed. São Paulo, ESALQ/USP, 1985. 467p.

GREGORY, P.J. Crecimiento y funcionamiento de las raíces. In: WILD, A., Coord. Condiciones del suelo y desarrollo de las plantas según Russel. Madrid, Mundi-Prensa, 1992. p.121-175.

IMHOFF, S.; SILVA, A.P. \& DEXTER, A.R. Factors contributing to the tensile strength and friability of Oxisols. Soil Sci. Soc. Am. J., 66:1656-1661, 2002.

INSTITUTO AGRONÔMICO DO PARANÁ - IAPAR. Cartas Climáticas do Paraná. Versão 1.0. 2000. CD ROM.

INSTITUTO BRASILEIRO DE GEOGRAFIA E ESTATÍSTICAS - IBGE. Rede Brasileira de Monitoramento Contínuo Relatório de Informação de Estação, Estação Guarapuava. Disponível em: <ftp://geoftp.ibge.gov.br/RBMC/relatorio/ Descritivo_PRGU.pdf>. Acesso em: 10 maio 2009.

KAMINSKI, J.; SANTOS, D.R.; GATIBONI, L.C.; BRUNETTO, G. \& SILVA, L.S. Eficiência da calagem superficial e incorporada precedendo o sistema plantio direto em um Argissolo sob pastagem natural. R. Bras. Ci. Solo, 29:573580,2005

KAY, B.D. \& DEXTER, A.R. The influence of dispersive clay and wetting/drying cicles on the tensile strength of a red-brown Earth. Austr. J. Soil Res., 30:297-310, 1992.

LEBRON, I.; SUAREZ, D.L. \& YOSHIDA, A.T. Gypsum effect on the aggregate size and geometry of three sodic soils under reclamation. Soil Sci. Soc. Am. J., 66:92-98, 2002.

MALIK, M.; AMRHEIN, C. \& LETEY, J. Polyacrylamide to improve water flow and sal removal in a high shrink-swell soil. Soil Sci. Soc. Am. J., 55:1664-1667, 1991.

MASCHIETTO, E.H.G. Gesso agrícola na produção de milho e soja em solo de alta fertilidade e baixa acidez em subsuperfície em plantio direto. Ponta Grossa, Universidade Estadual de Ponta Grossa, 2009. 56p. (Tese de Mestrado)

MELLO, I. \& RAIJ, B. van. No-till for sustainable agriculture in Brazil. Proc. World Assoc. Soil Water Conserv., 1:49-57, 2006. 
MISRA, R.; DEXTER, A. \& ALSTON, A. Penetration of soil aggregates of finite size. II. Plant roots. Plant Soil, 94:59$85,1986$.

MOHANDAS, S.; NAIDU, V. \& NAIDU, M. Catalytic effect of Ca on invertase activity in sugarcane. Trop. Agric., 60:148$150,1983$.

MUNEER, M. \& OADES, J.M. The role of Ca-organic interactions in soil aggregate stability. III. Mechanisms and models. Austr. J. Soil Res., 27:411-423, 1989.

NORTON, L.D. \& DONSTOVA, K.M. Use of soil amendments to prevent soil surface sealing and control erosion. Adv. Geoecol., 31:581-587, 1998.

OTHMER, H.; DIEKKRUGER, B. \& KUTILEK, M. Bimodal porosity and unsaturated hydraulic conductivity. Soil Sci., 152:139-150, 1991.

REICHERT, J.M.; REINERT, D.J. \& BRAIDA, J.A. Qualidade dos solos e sustentabilidade de sistemas agrícolas. Ci. Amb., 27:29-48, 2003.

ROSA JÚNIOR, E.J.; MARTINS, R.M.G.; ROSA, Y.B.C.J. \& CREMON, C. Calcário e gesso como condicionantes físico e químico de um solo de cerrado sob três sistemas de manejo. Pesq. Agropec. Trop., 36:37-44, 2006.

ROSA JUNIOR, E.J.; VITORINO, A.C.T. \& VITORINO, P.F.P.G. Efeito da calagem, gessagem e adubação fosfatada sobre algumas características físicas de um Latossolo Roxo Distrófico de Dourados-MS. R. Cient., 1:5-12, 1994.

SANTI, A.L. Relações entre indicadores de qualidade do solo e a produtividade das culturas em áreas com agricultura de precisão. Santa Maria, Universidade Federal de Santa Maria, 2007. 150p. (Tese de Doutorado)

SANTOS, A.O.; UNGARO, M.R.G. \& LINO, A.C.L. Considerações sobre o delineamento de zonas "potenciais" de manejo a partir de dados de solo-planta-clima. In: CONGRESSO BRASILEIRO DE AGRICULTURA DE PRECISÃO, 1., São Pedro, 2004. Anais... São Pedro, ESALQ/USP, 2004. CD ROM.

SHAINBERG, I.; SUMNER, M.E.; MILLER, W.P.; FARINA, M.P.W.; PAVAN, M.A. \& FEY. M.V. Use of gypsum on soils: A review. In: STEWART, B.A., ed. Advances in soil science. New York, Springer-Verlag, 1989. v.9. p.1-111.

SILVA, A.P. \& KAY, B.D. Estimating the least limiting water range of soils from properties and management. Soil Sci. Soc. Am. J., 61:877-883, 1997.

SILVA, S.R.; BARROS, N.F. \& COSTA, L.M. Atributos físicos de dois Latossolos afetados pela compactação do solo. R. Bras. Eng. Agríc. Amb., 10:842-847, 2006.
SILVA, V.R.; REINERT, D.J. \& REICHERT, J.M. Fatores controladores da compressibilidade de um Argissolo Vermelho-Amarelo distrófico arênico e de um Latossolo Vermelho distrófico típico. II - Grau de saturação em água. R. Bras. Ci. Solo, 26:9-15, 2002.

SIX, J.; BOSSUYT, H.; DEGRYZE, S. \& DENEF, K. A history of research on the link between (micro)aggregates, soil biota, and soil organic matter dynamics. Soil Tillage Res., 79:7-31, 2004.

STONE, L.F.; GUIMARÃES, C.M. \& MOREIRA, J.A.A. Compactação do solo na cultura do feijoeiro.I: Efeitos nas propriedades físico-hídricas do solo. R. Bras. Eng. Agric. Amb., 6:207-212, 2002.

THOMAS, G.A.; GIBSON, G.R.; NIELSEN, G.H.; MARTIN, W.D. \& RADFORD, B.J. Effects of tillage, stubble, gypsum, and nitrogen fertilizer on cereal cropping on a red-brown earth in southwest Queensland. Austr. J. Exper. Agric., 35:997-1008, 1995.

TIRADO-CORBALA, R. A lysimeter study of vadose zone porosity and water movement in gypsum amended soils. Columbus, Ohio State University, 2010. 238p. (Tese de Doutorado)

TIRADO-CORBALA, R. Micromorphology of gypsum amended soils from no-till fields in Ohio, USA. In: INTERNATIONAL ANNUAL MEETING OF THE ASA-CSSA-SSSA, Pittsburgh, 2009. Proceedings... Pittsburgh, ASA-CSSASSSA, 2009. Disponível em: <http://a-c-s.confex.com/ crops/2009am/web program/start.html>. Accessed: Jan 07, 2010.

TORMENA, C.A. \& ROLOFF, G. Dinâmica da resistência à penetração de um solo sob plantio direto. R. Bras. Ci. Solo, 20:333-339, 1996.

TORMENA, C.A.; ARAUJO, M.A.; FIDALSKI, J. \& COSTA, J.M. Variação temporal do intervalo hídrico ótimo de um Latossolo Vermelho distroférrico sob sistemas de plantio direto. R. Bras. Ci. Solo, 31:211-219, 2007.

TORMENA, C.A.; ARAUJO, M.A.; FIDALSKI, J.; IMHOFF, S. \& SILVA, A.P. Quantificação da resistência têncil e da friabilidade de um Latossolo Vermelho distroférrico sob plantio direto. R. Bras. Ci. Solo, 32:943-952, 2008.

TORMEnA, C.A.; ROLOFF, G. \& SÁ, J.C.M. Propriedades físicas do solo sob plantio direto influenciadas por calagem, preparo inicial e tráfego. R. Bras. Ci. Solo, 22:301-309, 1998. 
